\title{
The Influence of Service Convenience towards Consumer Continuance Usage Intention
}

\author{
Narehan Hassan ${ }^{1}$, Nur Hidayah Ayob², Nur Athirah Sumardi ${ }^{3}$, Mohd Safwan Ramli, \\ Mazuin Mat Halif \\ ${ }^{1}$ Faculty of Business and Management, Universiti Teknologi MARA (UiTM) Selangor Branch, Puncak Alam, Selangor, \\ Malaysia \\ ${ }^{2,4}$ Faculty of Business and Management, Universiti Teknologi MARA (UiTM) Jengka, Pahang, Malaysia \\ ${ }^{3}$ Universiti Malaysia Kelantan, Bachok, Kelantan, Malaysia \\ ${ }^{5}$ Faculty of Business and Management, Universiti Teknologi MARA (UiTM) Kelantan Branch, Machang, Kelantan, Malaysia \\ Email: ${ }^{1}$ drnarehan@ uitm.edu.my, ${ }^{2}$ hidayahayob@uitm.edu.my, ${ }^{3}$ athirah.s@umk.edu.my, ${ }^{4}$ safwanramli@uitm.edu.my, \\ ${ }^{5}$ mazui208@uitm.edu.my
}

Article Received: 20 September 2020, Revised: 30 November 2020, Accepted: 18 December 2020

\begin{abstract}
This research was conducted to examine the effects of service convenience dimensions (search convenience, evaluation convenience, transaction convenience, possession convenience and post purchase convenience) towards consumer continuance usage intention when using mobile shopping (m-shopping) application. In this study, data was collected using questionnaire as the instrument. Snowball sampling technique was applied distributed to mobile shoppers vie e-survey (google forms) within the period of one month. After the period, four hundred and twenty questionnaires were collected, but only three hundred and ninetynine were found usable for further analysis. The findings revealed that service convenience dimensions (search convenience, evaluation convenience and possession convenience) had positive influence on consumer continuance usage intention, whereas the other two sub-dimensions, which were transaction and post-purchase convenience did not influence future continuance intention. This research also suggests several recommendations for future research. Among others, future researchers could explore demographic and psychographic elements as the moderating variables, and to include extrinsic factors like buying situation to investigate if these variables could influence consumer continuance usage intention. Besides, it is suggested that future researchers to expand the theoretical framework by adding mediator or moderating variables.
\end{abstract}

Keywords

Mobile Shopping, Consumer Continuance Usage Intention, Service Convenience Dimensions, Consumer Generations

Article Received: XX Xxx 2021, Revised: XX Xxx 2021, Accepted: XX Xxx 2021

\section{Introduction}

In the South East Asian region, the use of smartphones for mobile shopping is growing in popularity. According to Nielsen (2014) survey of nearly 30,000 respondents in 60 nations, Malaysia was ranked sixth in the top 10 markets worldwide for mobile shopping, after the Philippines (62\%), Indonesia (61\%), Vietnam (58\%), Thailand (58\%) and Singapore (48\%). Malaysia has approximately 25.08 million active internet users in 2018 (79 percent of the population) and 21.6 million are mobile user (export.gov, 2018) and that the population has extremely high rates of mobile cellular penetration (Malaysian Digest, 2015). One third of Malaysians purchased goods and services by mobile shopping which was about 34\% (Nielsan, 2016). Nielsan (2016) also reported that $55 \%$ of Malaysian consumers felt anxious when their mobile devices are not close with them and three quarter reportedly say that their mobile devices make their lives better.

Mobile phones shopping (m-shopping) refers to the online search, browsing, comparison and purchase by consumers of goods and services via wireless handheld or mobile devices, smartphones, and tablets (Groß, 2015). Mshopping can also be described as an advanced $\mathrm{m}-$ service that enables consumers to browse or purchase goods and services from retailers anywhere and at any time via mobile devices (Yang, 2012). The positive impact of mobile technology is widely known especially to retailers where they can easily interact with consumers in a fast and easy manner. The main advantage of $\mathrm{m}-$ commerce is its accessibility; despite having small-screens, mobile platform has many advantages. Almost every retail industry is endeavoring to squeeze its business on mobile phone and making it convenient for consumers. 
The advancement of technology has made it easier for mobile shopping customers especially to generation $\mathrm{X}$ who is known for their computer savvy. A study conducted by Dhanapal, Vashu and Subramaniam (2015) found that generation X had a higher inclination towards m-shopping compared to baby boomers. Baby Boomers, on the other hand, were described as people who think hard work and dedication are the price to pay for success (Patterson \& Pegg, 2009). Generation X behaves more strongly than previous generations in terms of independence, resilience and adaptability. Similarly, the millennial or generation $\mathrm{Y}$ and generation $\mathrm{Z}$ grew up with modern technology - in essence, the computers and Internet are significant elements of their lives (Priporas, Stylos \& Fotiadis, 2017). Based on Billbooks (2015), consumers prefer to use mcommerce over e-commerce because of its userfriendly features and that consumers get to choose from a wide variety of options available. They shop within a few clicks without having to plug in the notebook and wait for the page to load. With the improved speed of internet connection and handy device, m-shopping is the choice for the younger generations of $\mathrm{X}, \mathrm{Y}$ and $\mathrm{Z}$.

\section{M-Shopping}

Mobile shopping ( $\mathrm{m}$-shopping) has been in existence for the past 16 years. The first study on m-shopping explored differences between mainstream and mobile technologies were conducted in 2002 (Pedersen, Methlie \& Thorbjornsen, 2002). Based on Nielsen's Mobile Shopping, Banking and Payment Report (2016), three out of five Malaysian consumers who could not even imagine life without mobile devices $(58 \%)$ and $(76 \%)$ believed their mobile devices helped improve their performance. Nearly twothirds of Malaysian respondents also admitted that face-to - face encounters were replaced by electronic media (65\%), but that could not be issue as more than half (52\%) said they favoured text over face-to - face encounters anyway.

Internet and e-commerce have led to a revolution in the last decade, especially in retail business to consumer (B2C) transactions. Retailers are focusing on marketing strategies and selling via mobile devices called mobile commerce with the increase in smartphones available to people and high-speed Internet connections. (m- commerce) (Musa et al., 2016). The estimated global market growth by the end of 2018 would be $\$ 626$ billion, accounting for $20.99 \%$ of the total digital trading market. (GSMA, 2016). M-shopping includes a range of tasks, such as ordering items, monitoring purchases, collecting bonuses and bonus points, receiving saved coupons, searching or product analysis, comparing goods, reading feedback, etc. (Mishra, Kesharwani, \& Das, 2016).

\section{Continuance Usage Intention}

According to Abbas and Hamdy (2015), Mshopping continuance usage intention is defined as a method of continuing to do business and repurchasing goods and services from the same company rather than switching to a competitor. Chang \& Zhu, (2012) testified that the synonym for the intention to continue can be referred to as post-adoption. Gao, Waecthter and Bai. (2015) defined consumers' continuance usage intention as continued use by consumers as their reengagement in m-shopping activities after purchase. It is difficult to retain existing users and to make it easier for consumers to continue buying goods and services through m-shopping. Reichheld and Schefter (2000) stated that the cost of obtaining a new user is five times that of retaining an existing user. According to the study by Bhattacherjee (2001), customer satisfaction with previous experience is a significant factor impacting consumers' continuing intent to use technology. The intention to measure continuity includes loyalty, switching, payment, including both external and internal responses (Abbas \& Hamdy, 2015). Customers' intention to repurchase a product or service is based on their perception of the value of the service (Chang, Kuo, Hsu \& Cheng, 2014). Hernandez-Ortega, Serrano-Cinca and Gomez-Meneses (2014) said that the desire to continuance intention has a close connection with other factors, such as expectations, and it is also important to anticipate the customer's future actions.

\section{Literature Review}

\section{Service Convenience}

Service convenience is characterized as buyers' time and exertion related with purchasing or using a service (Berry, Seiders \& Grewal, 2002). Based on Mahapatra's (2017) study, service convenience showed that the construct comprised of five major dimensions in service convenience. Berry et al. (2002) defined service convenience as the ability 
to accomplish a job with the least human energy consumption in the shortest time possible. In other words, saving time is a value of a reliable service and the reason why the customer is involved in the service itself (Brown, 1990). Five dimensions service continuances are reflected in key activities involving the service acquisition process. Specifically, it reflected the perceived time and effort to decide how to obtain a service, to reach and request a service, to secure the right to use a service, to experience the core benefit of the service, and to restart contact with the service provider after obtaining the benefit. (Berry et al., 2002). Service convenience can directly affect consumer satisfaction and lead to consumer loyalty (Berry et al., 2002). With an understanding of the service convenience offered, retailers can develop convenience strategies that can support customer relationships and increase their competitors to a new level. (Seiders, Berry \& Gresham, 2000). The more consumers experience the convenience of the service, the greater the satisfaction they would enjoy, thus enhancing the continued use of m-shopping. (Mahapatra, 2017).

\section{Search Convenience}

Search convenience can be described as the advantage in terms of information availability with the least amount of effort and time spent searching for information (Wang, Lin, Tai \& Fan, 2016). When using m-shopping, customers can study goods or services and compare prices without visiting several places physically to locate their desired items. (Jiang, Yang, \& Jun, 2013). Mobile shopping application offering useful and accurate information is considered convenient (Avery, 1996). Consumers usually feel more at ease when the platform offers the least effort and time to search for information for information on the product or service (Verhoef, Neslin \& Vroomen, 2007). There are four key elements that affect consumer perception when searching for product information: download speed, website design, search function and product classification (Jiang et al., 2013). Consumers would avoid a request for $\mathrm{m}$-shopping if the time and effort spent searching for information were high (Verhoef et al., 2007). In fact, a channel that is perceived to be more comprehensive in the processing of information has influenced consumer preference (Zhao, 2015). A digital platform that presents information in the form of text, tables, graphs, photos, audios, and videos that makes it more comprehensive and thus enriches the search experience would be advantageous. Based on Mahapatra's (2017) study, the search convenience had a significant or positive impact on the consumer 's continued use intention of $\mathrm{m}$ shopping.

\section{Evaluation Convenience}

Evaluation convenience is linked with the website of detailed yet easy-to - understand product descriptions using various presentation features, such as text and graphics. Evaluation convenience can be characterized as convenience of choice, which refers to the perception by consumers of the time and effort involved in planning product choices (Izquierdo-Yusta et al. 2014). According to Litan and Rivlin (2001), evaluation convenience assessment can improve consumer convenience and choice. Advanced technologies, such as mobile apps, enables consumers to quickly access, find, compare and order items and create a shopping list through a user-friendly interface and quick response codes. Mobile retail scenario helps consumers to create a virtual shopping assistant, search, ask, compare, and order products or services, and share information on the buying process across social networks. Moreover, several shopping sites have already set up a consumer review system, enabling new visitors to read comments or reviews of their product experience from other consumers before ordering. (Jiang et al., 2013). Thus, such a peer review system has proved to be very effective in saving time and effort for consumer assessment. Based on Mahapatra's (2017) study, evaluation of convenience has a positive relationship with the intention to continue the use of consumer. By using mobile phones, consumers can simplify pre-purchase activities, such as checking the availability of the product, and assessing alternatives, especially for low profile products (Mahaptra, 2017).

\section{Transaction Convenience}

Transaction convenience involves the consumer's perceived time and effort to complete a transaction, usually requiring payment (IzquierdoYusta et al. 2014). Based on Bendapudi and Berry (1997) study, transaction security and lack of privacy lead to financial risk associated with money transactions, which have a significant 
impact on channel choice. Clearly, consumers people worry about the unwanted revelation of confidential information or its misuse. The transaction-processing risk appears to be the most critical in situations where payment transactions are interrupted due to unstable or limited access to the Internet (Mahapatra, 2017). This may lead consumers to the risk of transaction processing having a negative impact on the consumer's intention to continue shopping. As a result, the anonymity and protection of mobile transactions made using smartphones for payments would discourage consumers from buying $\mathrm{m}$-shopping on a regular basis (Groß, 2015). According to Mahapatra (2017), transaction convenience has had an impact on the customer 's continued use intention relationship. Benoit et al., (2017) agreed transaction convenience has the greatest impact on service convenience on consumer satisfaction.

\section{Possession Convenience}

Possession convenience refers to the effort to purchase the desired products or to modify the transaction (Jiang et al., 2013). Purchase effort involves the cost of consumers regarding the time and difficulty of buying a product on a channel (Bhatnagar \& Ratchford, 2004). Consumers prefer a platform for faster transactions and ease of ownership. Consumers may not select a channel if they believe that the method is too complicated, particularly if it lacks the resources required to execute the task effectively (Park \& Kim, 2003). Furthermore, Consumers can inspect a product physically in a retail store and place orders on a mobile phone. Easy and prompt settlement of the transaction and possession assistance is related to convenience of purchase or possession (Forsythe et al., 2006). Possession convenience can influence channel choice (Laukkanen, 2007), while finalizing the purchase decision, consumers often want affirmations in the form of feedback. Smartphones are an opportunity to share information efficiency get assurance about the choice (Calrson \& Zmud, 1999). Insurance endorsement of purchase decision influences preferred channel (Forsythe \& Shi, 2003). study, Possession convenience has a positive relationship with the consumer's continued use intention (Jiang et al., 2013) but has shown no significant impact on customer loyalty (Jimenez et al., 2017).

\section{Post-Purchase Convenience}

Post-purchase convenience involved after-sales service and consumers can conveniently e-mail or call the support line to report service failure on site. Based on Hausman and Siekpe's (2009) study, responsive customer service is a key antecedent for the intention to visit or avoid a channel. Responsive service, such as timely with reliable after-sales and delivery, and advice also shaped shopping experience. (Chen \& Dibb, 2010). According to Berry et al. (2002), Postpurchase convenience is the perceived time and effort of consumers to restart contact with a company after the service has been provided. Mobile technology is the most attractive platform (Ko et al., 2005) in terms of "human message interaction" and "human-human interaction". The real-time management program provides the benefits of delivery service as promised (Srinivasan et al., 2002). Consumers may send email or call the help line to report service failure on site. Consumers seek urgent assistance by a cell phone helpline or a personal assistance program (Chiang \& Liao, 2012). Such initiative can include the need to contact the service providers after the sale has been completed to initiate service grievances or failures, request repairs or improvements or general service support (Wilson, Zeithaml \& Bitner, 2012). The concept of service convenience therefore provides for a mechanism by which the perceived time and effort of the consumer to purchase and consume services will inadvertently be reduced (Berry et al., 2002). The non-monetary benefit of the business product is enhanced by providing additional comfort for the consumer. Based on Mahapatra's (2017) study, post-purchase convenience had a positive relationship with the consumer's continued use intention and had an impact on consumer satisfaction. (Chang et al., 2010). After consumers have purchased goods or services, they can exchange goods or services and enforce the warranty when the package of goods is damaged (Benoit et al., 2017). However, postpurchase convenience does not show any significant impact on customer loyalty (Kaura et al., 2015).

\section{Conceptual Framework}

Figure 1 depicts the framework for the study adapted from Mahapatra (2017) under the title "Mobile shopping among young consumers:" An 
empirical study in an emerging market, mobile technology devices such are smartphones, tablets, laptops, computers and personal digital assistants (PDAs) can do the job the same as smartphones as a communication tool.

Figure 1: Conceptual Framework of the Study

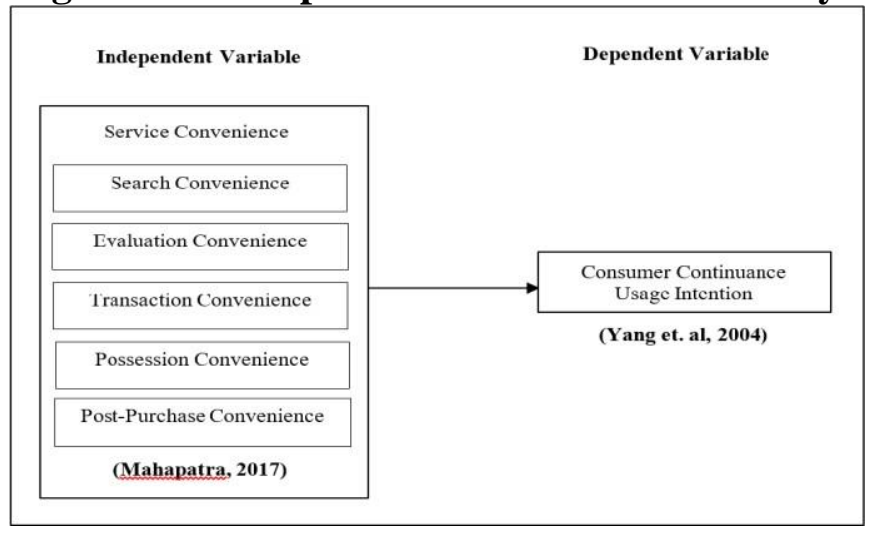

\section{Research Questions}

Two research questions are formulated in the study namely:

1. What is the relationship between service convenience dimensions and consumer continuance usage intention in m-shopping?

2. Which dimensions of service convenience predict consumer continuance usage intention in m-shopping?

\section{Methodology}

\section{Research Design}

In this study, correlational research was adopted as it depicts the natural environment of an organization with minimal intervention by a researcher with normal workflow. Correlational research is invariably conducted in non-contrived settings and cross-sectional or one-shot study. A study is conducted to gather data only once, perhaps over a period of days, weeks or months, to address a research query (Sekaran \& Bougie, 2016).

\section{Research Instrument}

In this study the questionnaire was used to as the survey instrument. Questionnaire can be characterized as a pre-formulated written collection of questions to which respondents record their responses, typically within specifically specified alternatives or a collection of structured questions designed to collect the data needed for study. (Sekaran \& Bougie, 2016). A good questionnaire can obtain accurate information from the respondents with low cost incurred and provides a structure to answer in an orderly fashion (Zainudin, 2012).

The questionnaire was divided into four (4) sections. Section A focused on general demographic information. General information consisted of respondents' information on the frequency of using $\mathrm{m}$-shopping, time spent browsing, favorite m-shopping vendors etc. Section B consisted of the service convenience dimensions. There were five dimensions of service convenience dimensions: search convenience, evaluation convenience, transaction convenience, possession convenience and postpurchase convenience. Meanwhile, Section C consisted of the consumers' continuance usage intention.

\section{Findings And Discussions}

The total usable questionnaires returned was 399. The respondents' demographic details are summarized in Table 1. It was found that majority of the respondents were female $(n=270,67.7 \%)$ from the age group of 21-30 years old $(n=222$, $40.1 \%$ ) and had monthly income of RM1000RM1999 ( $\mathrm{n}=115,28.8 \%)$. The most favorite Mshopping platform was Shopee $(n=162,40.6 \%)$.

Table 1: Respondents' Profile $(n=399)$

\begin{tabular}{llcc}
\hline \multicolumn{1}{c}{ Demographic details } & \multicolumn{1}{c}{ Description } & Frequencies & Percentage \\
\hline \multirow{2}{*}{ Gender } & Male & 129 & 32.3 \\
& Female & $\mathbf{2 7 0}$ & $\mathbf{6 7 . 7}$ \\
\hline \multirow{3}{*}{ Age } & 20 years and below & 58 & 13.7 \\
& $\mathbf{2 1}-\mathbf{3 0}$ years old & $\mathbf{2 2 2}$ & $\mathbf{4 0 . 1}$ \\
& $31-40$ years old & 86 & 31.1. \\
& $41-50$ years old & 25 & 11.8 \\
& 51 Years old and above & 8 & 2.0 \\
\hline
\end{tabular}




\begin{tabular}{llcc}
\hline & Below RM999 & 57 & 14.3 \\
& RM1000-RM1999 & $\mathbf{1 1 5}$ & $\mathbf{2 8 . 8}$ \\
& RM2000- RM2999 & 79 & 19.8 \\
& RM3000- RM3999 & 31 & 7.8 \\
& RM4000-RM4999 & 24 & 6.0 \\
& RM5000 and above & 45 & 11.3 \\
& No Salary & 48 & 12.0 \\
\hline \multirow{5}{*}{ Most Favourite M-Shopping } & Lazada & 158 & 39.6 \\
& Zalora & 25 & 6.3 \\
& Shopee & 27 & 6.8 \\
& Others & $\mathbf{1 6 2}$ & $\mathbf{4 0 . 6}$ \\
& & 27 & 6.8 \\
\hline
\end{tabular}

$R Q$ 1: What is the relationship between service convenience and consumer continuance usage intention in m-shopping?

Table 2 illustrates the relationship between independent and dependent variables which will be interpreted by using Cohen (1988) guidelines. It was found that there was a significant, large and positive relationship between service convenience and consumer continuance usage intention in $\mathrm{m}$ shopping $(\mathrm{r}=.518, \mathrm{p}<0.01)$. Mahapatra (2017) also found that consumers' continuance usage intention often resulted from their previous positive purchase experiences. Therefore, further analyses were conducted on the relationships between dimensions of service convenience and consumers' continuance usage intention in $\mathrm{m}$ shopping which is summarized in Table 3.

Table 2: Correlation between Service Convenience and Consumer Continuance Usage Intention in M-Shopping.

\begin{tabular}{|ccc|}
\hline & $\begin{array}{c}\text { Consumer continuance } \\
\text { usage intention in m- } \\
\text { shopping }\end{array}$ \\
\hline Service $\quad \begin{array}{l}\text { Pearson } \\
\text { Correlation }\end{array}$ & $.518^{* *}$ \\
Convenience & Sig. (2- & .000 \\
tailed) & 399 \\
$\mathrm{~N}$ & \\
\hline
\end{tabular}

Correlation is significant at the 0.01 level (2tailed).

A specific correlational analysis was conducted to determine the relationships between dimensions of service convenience and consumer continuance usage intention. The findings are tabulated in Table 3 which will be interpreted according to the guidelines by Cohen (1988). It was discovered that all five dimensions of service conveniences had significant and positive relationships with consumer continuance usage intention in $\mathrm{m}$ shopping. In fact, search convenience, evaluation convenience, transaction convenience and possession convenience were found to have large and positive relationships with consumer continuance usage intention in m-shopping $(\mathrm{r}=.666, \mathrm{p}<0.01 ; \mathrm{r}=.598, \mathrm{p}<0.01 ; \mathrm{r}=.587, \mathrm{p}<0.01$; $\mathrm{r}=.524, \mathrm{p}<0.01$ respectively). Meanwhile, postpurchase convenience was the only dimension with moderate positive relationship with the dependent variable $(r=.406, p<0.01)$ which is still demonstrating the parallel direction of relationships like the other four dimensions. These positive relationships have signified that 'the greater the search, evaluation, transaction, possession and post-purchase conveniences, the greater the continuance usage intention in mobile shopping'. These findings are supported by $\mathrm{Xu}$, Huang and Li (2019) who found that convenience may affect both consumers' continuance usage intention and behavior in using mobile applications for tourism. Whether it is shopping or travelling, it can be concluded that consumers are very particular about convenience aspect especially if they want to continuously use certain platform as their main medium of purchasing or information search.

\section{Table 3: Correlations between Dimensions of Service Convenience and Consumer Continuance Usage Intention.}

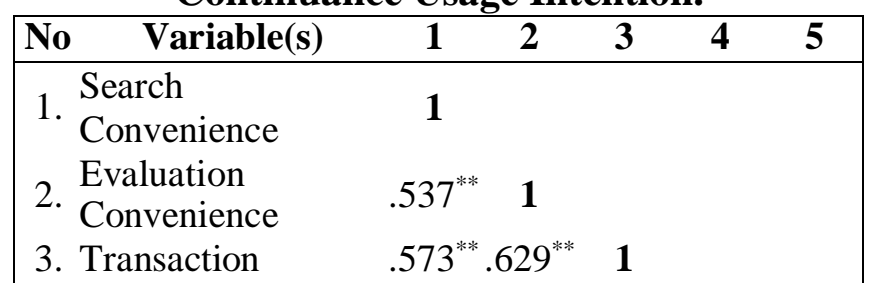


Convenience

4. Possession

4. Convenience

5. Post-Purchase

Convenience

Consumer

6. Continuance Usage $\mathbf{. 6 6 6}^{* *} . \mathbf{5 9 8}^{* *} . \mathbf{5 8 7 ^ { * * }} \mathbf{. 5 2 4}^{* *} . \mathbf{4 0 6}$ Intention

** Correlation is significant at the 0.01 level (2tailed).

$R Q$ 2: Which dimension of service convenience that has the greatest influence towards the consumer continuance usage intention in $m$ shopping?

Table 4 shows the results of multiple regression analysis in determining the predictors of service convenience towards the consumers' continuance usage intention. It was found that the $\mathrm{R}^{2}$ value was 0.569 in which all dimensions comprised of service convenience are explained $56.9 \%$ of the variance for consumer continuance usage intention. The Durbin Watson value for this study was 1.808 , which was good as it fell within the range of 1.5 to 2 , in line with the multivariate analysis' assumptions. Moreover, the findings have shown that search convenience is the most influential dimension of service convenience towards consumer continuance usage intention $(\beta=0.352, p<0.05)$, followed by possession and evaluation convenience as the second and third dimensions with the most influence towards the dependent variable $(\beta=0.245, p<0.05 ; \beta=0.217$, $\mathrm{p}<0.05$ respectively).

In the meantime, transaction and post-purchase convenience dimensions were found to have no influence towards the consumer continuance usage intention $(\beta=0.086, \quad p>0.05 ; \beta=0.063$, p>0.05 respectively). Therefore, it can be concluded through these findings that only three out of five dimensions of service convenience acted as predictors towards the study's dependent variable which is consumers' continuance usage intention.

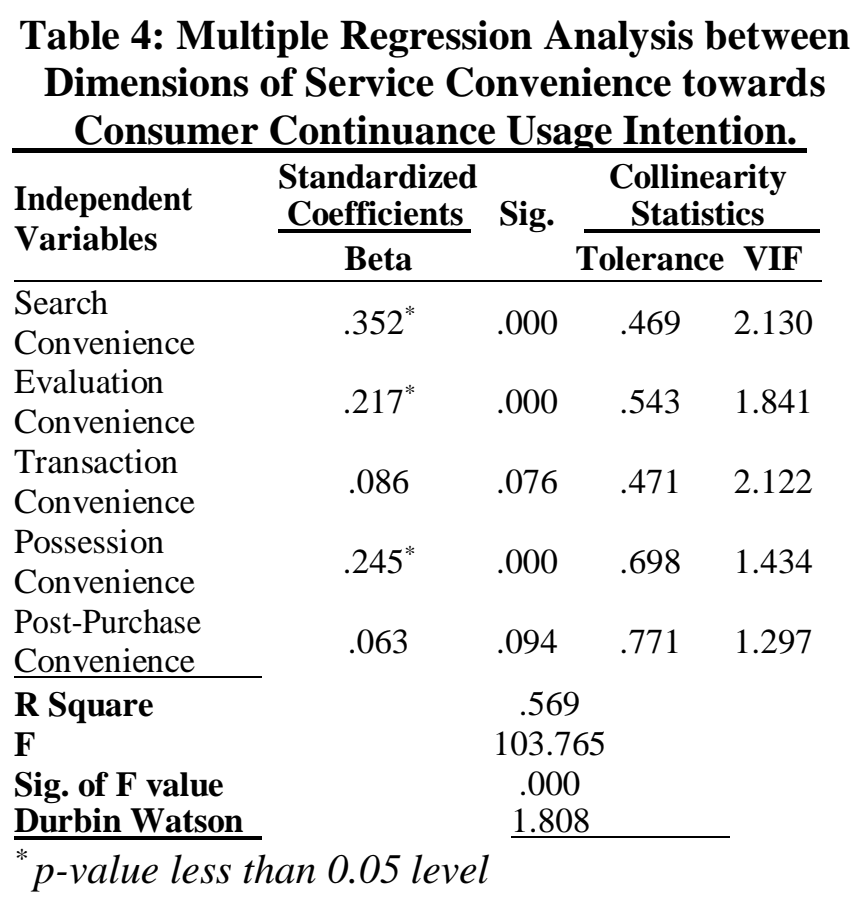

\section{Conclusion And Recommendations}

Based on the findings, respondents believed that using service convenience can influence consumer continuance usage intention. This has significantly supported the fact that with the advancement of technology and availability of smartphones, have enhanced the way people participate in $\mathrm{m}$ shopping. Traditionally, when consumers buy a product, they need to transfer money through Cash Deposit Machine (CDM). This act needs effort and time. However, consumers these days are time concern and calculative in the effort that needs to be exerted. M-shopping changed the traditional way of online shopping by enhancing the experience with seamless connectivity and timely services.

Based on the findings, there are several dimensions of service convenience that are significant as predictors towards consumers' continuance usage intention. Based on search convenience, consumers can search products and compare prices without physically having to visit multiple locations to find their desired products. In relation to evaluation convenience, consumers can log on to the review system, allowing visitors to read other consumers' comments or reviews about their products experience before making purchases. In addition, for possession convenience, consumers can enjoy the luxury of having the product especially big bulk item to be delivered at their doorstep. The service convenience is element acts to influence 
consumers' continuance usage intention. If the retailers meet the customers' expectation, they tend to say positive things and recommend the products truthfully at the website. Similarly, if the product is perceived to have sub-standard service or value, consumers will not recommend it-all in the apps for others to evaluate freely.

This study contributes to mobile commerce research by empirically testing the influence of service convenience dimensions and consumer continuance usage intention on in using $\mathrm{m}$ shopping. Hence, it provides several interesting highlights for practical development and academic research on mobile retail services. In the Malaysian context, future research is needed to further develop the framework model outlined in this study. Future research may replicate the study in other countries. Besides, the sampling technique for future research can be improved by having focus groups of psychographics using other techniques such as quota sampling or cluster sampling group. In addition, moderating roles of demographics, diverse generations of $\mathrm{m}$-shoppers and market segmentation can be tested in future research studies. The extrinsic factor, such as the purchase situation can also be investigated as a mediator or moderator for the future.

\section{Acknowledgement}

The researchers would like to express the deepest appreciation to respondents for their permission and wonderful cooperation during the conduct of this research. In addition, the researchers would also like to acknowledge Universiti Teknologi MARA through its Institute for Research Management and Innovation (IRMI) for partial funding of the research.

\section{References}

[1] Abbas, H. A., \& Hamdy, H. I. (2015). Determinants of continuance intention factor in Kuwait communication market: Case study of Zain-Kuwait. Computers in Human Behavior, 49, 648-657.

[2] Agrawal, D. P., \& Zeng, Q. A. (2015). Introduction to wireless and mobile systems. Cengage learning.

[3] Avery, R. J. (1996). Determinants of search for nondurable goods: An empirical assessment of the economics of information theory. Journal of Consumer Affairs, 30(2), 390-420.
[4] Bendapudi, N., \& Berry, L. L. (1997). Customers' motivations for maintaining relationships with service providers. Journal of retailing, 73(1), 15-37.

[5] Benoit, S., Klose, S., \& Ettinger, A. (2017). Linking service convenience to satisfaction: dimensions and key moderators. Journal of Services Marketing, 31(6), 527-538.

[6] Berry, L. L., Seiders, K., \& Grewal, D. (2002). Understanding service convenience. Journal of marketing, 66(3), 1-17.

[7] Bhatnagar, A., \& Ratchford, B. T. (2004). A model of retail format competition for nondurable goods. International Journal of Research in Marketing, 21(1), 39-59.

[8] Bhattacherjee, A. (2001). Understanding information systems continuance: an expectation-confirmation model. MIS quarterly, 351-370.

[9] Billbooks (2015, June 02), "Is m-commerce overpowering the traditional e-commerce".

Retrieved from

http://www.nielsen.com/my/en/pressroom/2014/e- commerce.html

[10] Brown, L. G. (1990). Convenience in services marketing. Journal of Services Marketing, 4(1), 53-59.

[11] Carlson, J. R., \& Zmud, R. W. (1999). Channel expansion theory and the experiential nature of media richness perceptions. Academy of management journal, 42(2), 153-170.

[12] Chang, K. C., Kuo, N. T., Hsu, C. L., \& Cheng, Y. S. (2014). The impact of website quality and perceived trust on customer purchase intention in the hotel sector: website brand and perceived value as moderators. International Journal of Innovation, Management and Technology, 5(4), 255.

[13] Chang, Y. P., \& Zhu, D. H. (2012). The role of perceived social capital and flow experience in building users' continuance intention to social networking sites in China. Computers in Human Behavior, 28(3), 995-1001.

[14] Chen, J., \& Dibb, S. (2010). Consumer trust in the online retail context: Exploring the antecedents and consequences. Psychology \& Marketing, 27(4), 323-346.

[15] Chiang, I. P., \& Liao, Y. S. (2012, March). Exploring the key success factors of mobile 
commerce in Taiwan. In Advanced Information Networking and Applications Workshops (WAINA), 2012 26th International Conference on (pp. 369-374). IEEE.

[16] Cohen, J. (1988). Statistical power analysis for the behavioral sciences (2nd ed.).

Hilsdale, NJ: Lawrence Earlbaum

[17] Davis, F. D. (1989). Perceived usefulness, perceived ease of use, and user acceptance of information technology. MIS quarterly, 319340.

[18] Dhanapal, S., Vashu, D., \& Subramaniam, T. (2015). Perceptions on the challenges of online purchasing: a study from "baby boomers", generation " $\mathrm{X}$ " and generation "Y" point of views. Contaduría $y$ Administración, 60, 107-132.

[19] Economy, G. G. M. (2016). GSMA, 2016 2016.

[20] Forsythe, S., Liu, C., Shannon, D., \& Gardner, L. C. (2006). Development of a scale to measure the perceived benefits and risks of online shopping. Journal of interactive marketing, 20(2), 55-75.

[21] Forsythe, S.M. and Shi, B. (2003), Customer patronage and risk perceptions in internet shopping, Journal of Business Research, 56(5), 867-875.

[22] Fujimoto, Y., Ferdous, A. S., Sekiguchi, T., \& Sugianto, L. F. (2016). The effect of mobile technology usage on work engagement and emotional exhaustion in Japan. Journal of Business Research, 69(9), 3315-3323.

[23] Gao, L., Waechter, K. A., \& Bai, X. (2015). Understanding consumers' continuance intention towards mobile purchase: A theoretical framework and empirical studyA case of China. Computers in Human Behavior, 53, 249-262.

[24] Groß, M. (2015). Mobile shopping: a classification framework and literature review. International Journal of Retail \& Distribution Management, 43(3), 221- 241.

[25] Hausman, A. V., \& Siekpe, J. S. (2009). The effect of web interface features on consumer online purchase intentions. Journal of Business Research, 62(1), 5-13.

[26] Hernandez-Ortega, B., Serrano-Cinca, C., \& Gomez-Meneses, F. (2014). The firm's continuance intentions to use inter- organizational ICTs: The influence of contingency factors and perceptions. Information \& Management, 51(6), 747-761.

[27] Izquierdo-Yusta, A., Martínez-Ruiz, M. P., \& Álvarez-Herranz, A. (2014). What differentiates Internet shoppers from Internet surfers? The Service Industries Journal, 34(6), 530-549.

[28] Jiang, L., Yang, Z., \& Jun, M. (2013). Measuring consumer perceptions of online shopping convenience. Journal of Service Management, 24(2), 191-214.

[29] Jiménez, N., \& San-Martín, S. (2017). Attitude toward m-advertising and $\mathrm{m}$ repurchase. European Research on Management and Business Economics, 23(2), 96-102.

[30] Kaura, V., Durga Prasad, C. S., \& Sharma, S. (2015). Service quality, service convenience, price and fairness, customer loyalty, and the mediating role of customer satisfaction. International Journal of Bank Marketing, 33(4), 404-422.

[31] Ko, H., Cho, C. H., \& Roberts, M. S. (2005). Internet uses and gratifications: A structural equation model of interactive advertising. Journal of advertising, 34(2), 57-70.

[32] Kupperschmidt, B., 2000. Multigeneration employees: strategies for effective management. The Health Care Manager 19 (1), 65-76.

[33] Laukkanen, T. (2007). Customer preferred channel attributes in multi-channel electronic banking. International Journal of Retail \& Distribution Management, 35(5), 393-412.

[34] Litan, R. E., \& Rivlin, A. M. (2001). Projecting the economic impact of the Internet. The American Economic Review, 91(2), 313-317.

[35] Mahapatra, S. (2017). Mobile shopping among young consumers: an empirical study in an emerging market. International Journal of Retail \& Distribution Management, 45(9), 930-949.

[36] Mishra, M. K., Kesharwani, A., \& Das, D. (2016). The relationship between risk aversion, brand trust, brand affect and loyalty. Journal of Indian Business Research.

[37] Musa, R., Saidon, J., Harun, M. H. M., Adam, A. A., Dzahar, D. F., Haussain, S. S., \& Lokman, W. M. W. (2016). The predictors 
and consequences of consumers' attitude towards mobile shopping application. Procedia economics and finance, 37, 447452.

[38] Nielsen (2014, August 27). "Malaysians rank among the world's most avid online shoppers". Retrieved from http://www.nielsen.com/my/en/pressroom/2014/e- commerce.html

[39] Nielsen (2016, October 17). "Mobile ecology: are Malaysian consumers ready for the frontier of mobile banking \& payment"? Retrieved from http://www.nielsen.com/my/en/insights/news /2016/are-malaysian-consumers- embracingthe-virtual-wallet.html

[40] Park, C. H., \& Kim, Y. G. (2003).

Identifying key factors affecting consumer purchase behavior in an online shopping context. International Journal of Retail \& Distribution Management, 31(1), 16-29.

[41] Patterson, I., \& Pegg, S. (2009). Marketing the leisure experience to baby boomers and older tourists. Journal of Hospitality Marketing \& Management, 18(2-3), 254272.

[42] Pedersen, P. E., Methlie, L. B., \& Thorbjornsen, H. (2002, January). Understanding mobile commerce end-user adoption: a triangulation perspective and suggestions for an exploratory service evaluation framework. In System Sciences, 2002. HICSS. Proceedings of the 35th Annual Hawaii International Conference on (pp. 8-pp). IEEE.

[43] Priporas, C. V., Stylos, N., \& Fotiadis, A. K. (2017). Generation Z consumers' expectations of interactions in smart retailing: A future agenda. Computers in Human Behavior, 77, 374-381.

[44] Reichheld, F. F., \& Schefter, P. (2000). Eloyalty: your secret weapon on the web. Harvard business review, 78(4), 105113.Education Inc.

[45] Seiders, K., Voss, G. B., Godfrey, A. L., \& Grewal, D. (2007). SERVCON: development and validation of a multidimensional service convenience scale. Journal of the Academy of Marketing Science, 35(1), 144-156.

[46] Sekaran, U., \& Bougie, R. (2016). Research methods for business: A skill building approach. John Wiley \& Sons.

[47] Srinivasan, S. S., Anderson, R., \& Ponnavolu, K. (2002). Customer loyalty in ecommerce: an exploration of its antecedents and consequences. Journal of retailing, 78(1), 41-50.

[48] Verhoef, P. C., Neslin, S. A., \& Vroomen, B. (2007). Multichannel customer management: Understanding the research-shopper phenomenon. International Journal of Research in Marketing, 24(2), 129-148.

[49] Wang, Y. M., Lin, H. H., Tai, W. C., \& Fan, Y. L. (2016). Understanding multi-channel research shoppers: an analysis of Internet and physical channels. Information systems and e-business management, 14(2), 389-413.

[50] Wilson, A., Zeithaml, V. A., Bitner, M. J., \& Gremler, D. D. (2012). Services marketing: Integrating customer focus across the firm. McGraw Hill.

[51] Xu, F., Huang, S. S., \& Li, S. (2019). Time, money, or convenience: what determines Chinese consumers' continuance usage intention and behavior of using tourism mobile apps? International Journal of Culture, Tourism and Hospitality Research, 13(3).

[52] Yang, K. (2012). Consumer technology traits in determining mobile shopping adoption: An application of the extended theory of planned behavior. Journal of Retailing and Consumer Services, 19(5), 484-491.

[53] Yang, Z., Jun, M., \& Peterson, R. T. (2004). Measuring customer perceived online service quality: scale development and managerial implications. International Journal of Operations \& Production Management, 24(11), 1149-1174.

[54] Zainudin, A. (2012). Structural equation modeling using AMOS graphic. Shah Alam: Universiti Teknologi MARA Publication Centre (UPENA).

[55] Zhao, K. (2015). research on consumer online purchasing decision and its influencing factors: take Taobao as example. 